\title{
Influence of Sodium Hypochlorite and Chlorhexidine on the Dynamic Cyclic Fatigue Resistance of XP Endo Shaper Instruments
}

\author{
Alexandra Aparecida Tanomaru ${ }^{1}$ Ana Grasiela Limoeiro ${ }^{2}$ Adriana de Jesus Soares ${ }^{3}$ \\ Elson Lopes Medeiros Junior ${ }^{1}$ Gabriel Rocha Campos ${ }^{1}$ Sílvia Kaoru Hamasaki ${ }^{1}$ \\ Wayne Martins Nascimento ${ }^{1}$ Luiz Meton Horta ${ }^{1}$ Paula Avelar da Silva Ribeiro Goulart ${ }^{1}$ \\ Viviane Rangel do Couto ${ }^{1}$ Patrícia Bastos Alves ${ }^{1}$ Verônica Magalhães ${ }^{1}$ Danilo De Luca Campos ${ }^{1}$ \\ Marcos Frozoni ${ }^{1}$
}

${ }^{1}$ Department of Endodontics, São Leopoldo Mandic Dental Research Center, Campinas, São Paulo, Brazil

${ }^{2}$ Department of Endodontics, Ilhéus School of Dentistry, Ilhéus, Bahia, Brazil

${ }^{3}$ Department of Restorative Dentistry, Piracicaba Dental School, State University of Campinas- UNICAMP, Piracicaba, São Paulo, Brazil
Address for correspondence Ana Grasiela da Silva Limoeiro, PhD, Department of Endodontics, Ilhéus School of Dentistry, Rua Castro Alves, 100, Centro, Iguaí-BA, Zip: 45.280-000, Brazil (e-mail: grasielalimoeiro@gmail.com).

Eur J Dent 2022;16:580-584.

\section{Abstract \\ Keywords \\ - chlorhexidine digluconate \\ - irrigation solutions \\ - sodium hypochlorite \\ - XP-Endo Shaper}

Objective This study evaluated the dynamic cyclic fatigue resistance of the XP-Endo Shaper (XPS), associated with chlorhexidine digluconate (CHX) or sodium hypochlorite $(\mathrm{NaOCl})$ in two different formulations: gel $(\mathrm{G})$ or liquid $(\mathrm{L})$.

Materials and Methods Sixty XPS were used in an artificial stainless-steel canal, and the files were fully immersed in the irrigating solution throughout the experiment until the fracture. The files were divided into six groups $(n=10)$ based on the irrigation solution used: $\mathrm{NaOCl}(\mathrm{L}), \mathrm{NaOCl}(\mathrm{G}), \mathrm{CHX}(\mathrm{L}), \mathrm{CHX}(\mathrm{G})$, natrosol gel (NAT) (control), and lubricating oil (LO) (control). The artificial canal was manufactured $1.5 \mathrm{~mm}$ wide, $20 \mathrm{~mm}$ long, and, $3.5 \mathrm{~mm}$ deep with a straight cervical segment measuring $14.29 \mathrm{~mm}$; an apical segment of $4.71 \mathrm{~mm}$ with $3 \mathrm{~mm}$ radius; and 90 degrees of curvature apical $1 \mathrm{~mm}$ long straight segment. Resistance to cyclic fatigue was determined by recording the number of cycles to fracture (NCF).

Results The $\mathrm{CHX}(\mathrm{G}), \mathrm{CHX}(\mathrm{L})$, and OIL (LO) groups showed no significant difference between them and presented longer time to fracture $(p>0.05)$. $\mathrm{NaOCI}(\mathrm{L})$ shows the lowest NCF without significant differences between $\mathrm{NaOCl}(\mathrm{G})$ and NAT. The NCF of the $\mathrm{NaOCl}(\mathrm{G})$ was statistically similar to the $\mathrm{CHX}(\mathrm{L})$ and statistically lower than the $\mathrm{CHX}(\mathrm{G})$ and OIL groups. NAT did not present a statistical difference of the $\mathrm{NaOCI}(\mathrm{L}), \mathrm{NaOCl}(\mathrm{G})$, and presented a significantly lower NCF than the $\mathrm{CHX}(G)(p<0.01)$.

Conclusion The use of $\mathrm{CHX}(\mathrm{G})$ resulted in increased cyclic fatigue resistance of the XPS instruments compared to $\mathrm{NaOCl}$ or LO. published online

December 22, 2021
DOI https://doi.org/ 10.1055/s-0041-1735934. ISSN 1305-7456.
(C) 2021. The Author(s).

This is an open access article published by Thieme under the terms of the Creative Commons Attribution License, permitting unrestricted use, distribution, and reproduction so long as the original work is properly cited. (https://creativecommons.org/licenses/by/4.0/)

Thieme Medical and Scientific Publishers Pvt. Ltd., A-12, 2nd Floor, Sector 2, Noida-201301 UP, India 


\section{Introduction}

The development of new nickel-titanium (NiTi) alloy led to a higher success rate of root canal treatment, reducing clinical time and instrument fracture. ${ }^{1}$ The XP-Endo Shaper (XPS; FKG, La Chaux-de-Fonds, Switzerland) plays a leading role in chemomechanical preparation and root canal disinfection. It is made of MaxWire alloy² offers high flexibility and fatigue resistance; and can penetrate the canals easily and quickly, expanding or contracting, increasing canal volume, surface area, percentage of touched walls, and the amount of dentin removed. ${ }^{3}$ This single file system is associated with a lower frequency of postoperative pain compared to multi-instrument files, ${ }^{4}$ is effective in bacterial reduction of oval root canals with necrotic pulps, ${ }^{4}$ and is also indicated for use in curved canals as it has the ability to maintain the original shape with minimal transport. ${ }^{5}$

However, endodontic files are unable to reach all root canal walls, ${ }^{6}$ chemical substances assume a fundamental role in acting in these places where the instrument cannot reach. ${ }^{7}$ Of all the substances currently used for root canal irrigation, sodium hypochlorite $(\mathrm{NaOCl})$ seems ideal because it meets more requirements than any other known irrigating solution. ${ }^{8,9}$ The most used formulation of $\mathrm{NaOCl}$ is liquid $\mathrm{NaOCl}$ (L). However, it is potentially toxic in its liquid formulation when in contact with periapical tissues. ${ }^{10}$ The sodium hypochlorite gel form $\mathrm{NaOCl}(\mathrm{G})$ reduces the risk of debris extrusion into periapical tissues, ${ }^{11}$ and it is effective in reducing Enterococcus faecalis biofilm, but this effect is less than that of $\mathrm{NaOCl}$ liquid. ${ }^{12}$

Chlorhexidine digluconate (CHX) is an option for endodontic irrigants that could replace hypochlorite with some limitation. ${ }^{13} \mathrm{CHX}$ is a cationic compound with excellent antibacterial properties. ${ }^{14}$ It has shown antimicrobial activity against both forms of intracanal bacterial growth (planktonic and biofilm bacteria), ${ }^{13}$ and its contact with vital tissues presents low toxicity. ${ }^{13}$ For root canal chemomechanical preparation, $\mathrm{CHX}$ can be used in a liquid $\mathrm{CHX}(\mathrm{L})$ or a gel $\mathrm{CHX}(\mathrm{G})$ presentation. $\mathrm{CHX}(\mathrm{G})$ consists of a gel base (natrosol, a hydroxyethyl cellulose; $\mathrm{pH}=6-9$ ) and chlorhexidine gluconate. ${ }^{15} \mathrm{CHX}(\mathrm{G})$ formulation can perfectly replace the $\operatorname{CHX}(\mathrm{L})$, improving the reduction of smear layer formation, compensating for its incapacity to dissolve organic tissues. It has a better residual effect due to its substantivity (up to 24 hours). ${ }^{15}$ The gel formulation may keep the active principle of CHX in contact with the microorganisms for a longer time, inhibiting their growth. ${ }^{16} \mathrm{~A}$ brown precipitate is formed by mixing $\mathrm{NaOCl}$ and CHX. ${ }^{17}$

Despite technological innovations in endodontics, fractures from mechanized NiTi instruments still occur in two ways: torsional or cyclic fracture. ${ }^{18}$ Therefore, the present study aimed to evaluate the dynamic cyclic fatigue resistance of the XPS files in association with two solutions in different formulations: $\mathrm{NaOCl}(\mathrm{L}), \mathrm{NaOCl}(\mathrm{G}), \mathrm{CHX}(\mathrm{L})$, and $\mathrm{CHX}(\mathrm{G})$. The null hypothesis was that the different irrigants do not influence the XPS files' dynamic cyclic fatigue resistance at body temperature.

\section{Materials and Methods}

The sample size and power for statistical testing were calculated by analyzing variance using the software $\mathrm{G}^{*}$ Power 3.1.9.4. For the effect size of 0.571 , obtained from a pilot study ( $n=3)$, the significance level of $5 \%$, and power of $90 \%$, the sample calculation indicated the need for 60 files $(n=10)$ in the present study.

Sixty 25-mm long XPS instruments were equally assigned to six groups $(n=10)$ based on the irrigating solution, $\mathrm{CHX}(\mathrm{L})$ chlorhexidine liquid $2 \%$ (Arte \& Vida, Bom Jesus de Itabapoana, RJ, Brazil); CHX(G) chlorhexidine gel $2 \%$ (Arte \& Vida, Bom Jesus de Itabapoana, RJ, Brazil); $\mathrm{NaOCl}(\mathrm{L})$ sodium hypochlorite liquid 5,25\% (Fórmula \& Ação, SP, Brazil); $\mathrm{NaOCl}(\mathrm{G})$ sodium hypochlorite gel 3\% (Fórmula \& Ação, SP, Brazil); NAT natrosol gel (Fórmula \& Ação, SP, Brazil) (control group), LO lubricating oil WD-40 (Ap Winner Ind, Ponta Grossa, PR, Brazil) (control group).

The files were inspected for deformities at high magnification $(13.6 \times)$ (Zeiss Pico; Carl Zeiss MediTec, Dublin, California, United States), and none of them was discarded. Noncorrosive stainless-steel blocks against $\mathrm{NaOCl}$ or $\mathrm{CHX}$ were used to test resistance to dynamic cyclic fracture. The artificial canal was $1.5 \mathrm{~mm}$ wide, $20 \mathrm{~mm}$ long, and $3.5 \mathrm{~mm}$ depth, with a straight cervical segment of $14.29 \mathrm{~mm}$, a long curved apical segment of $4.71 \mathrm{~mm}$ with a radius of $3 \mathrm{~mm}$ and a curvature of 90 degrees, and a long straight apical segment of $1 \mathrm{~mm} .{ }^{19}$

These dimensions allow the file to rotate freely within the artificial canal, both angularly and in a dynamic motion. The canal was covered with an acrylic plate to prevent instrument slippage, visualize the instrument during its action, and keep the irrigating solution within the simulated canal. The interface between the metallic block and the acrylic plate around the metallic canal was sealed with silicon (Pulvitec Polystic, São Paulo, SP, Brazil) to prevent leakage and keep the simulated canal full of irrigating solution. The irrigating solution was inserted into the simulated canal by using a 3-mL syringe (Ultradent Products Inc - EUA) and needle Navitip 30G $21 \mathrm{~mm}$ long (Ultradent Products Inc EUA).

The stainless-steel block with the artificial canal was positioned vertically on a heating plate (Fisatom, São Paulo, SP, Brazil) at a constant temperature $\left(37^{\circ} \mathrm{C} \pm 1^{\circ} \mathrm{C}\right)$, measured by a laser thermometer pointed at the simulated canal (MT320 Minipa, Joinville, SC, Brazil), so the substance temperature into the root canal was accurately measured.

The contra-angle handpiece was fixed to the mechanical system that enables a dynamic axial movement of the file inside the simulated canal. The mechanical motion system consists of a linear guide, coupled with a savox sc-12 56t69 engine (Savox, Taichung, Taiwan) that performs back and forth movements, controlled by an electronic device that controls the speed amplitude of the axial movement. The files were placed inside the simulated canal coupled to a 6:1 reduction handpiece (Sirona Dental Systems GmbH, Bensheim, Germany), driven by a VDW Silver Reciproc motor (VDW, Munich, Germany). Cyclic fatigue tests were 
performed by rotating the instruments in continuous rotation at $800 \mathrm{rpm}$ and torque of $1 \mathrm{Ncm}$.

The instruments were inserted $20 \mathrm{~mm}$ into the canal, fitted with a silicone stop to register this length. A backand-forth axial movement at a speed of $3.0 \mathrm{~mm} / \mathrm{s}$ and amplitude of $3.0 \mathrm{~mm}$ were applied to the instruments to simulate clinical pecking motion. The continuous rotation of the file's movement occurred until the fracture could be visually observed. The file movement within the simulated canal was recorded with iPhone 6s (Apple Inc. Cupertino, California, United States), using $4 \mathrm{~K}$ recording technology. The movie was analyzed in Microsoft Movie Maker (Redmond, Washington, United States), and the time at which the instrument began to rotate until the moment of the fracture was registered in seconds. The number of cycles to fracture (NCF) was calculated by using the following formula: $\mathrm{NCF}=$ time (seconds) $\times$ revolution per minute $/ 60$.

The fragment lengths were measured by using a $150-\mathrm{mm}$ digital caliper (accuracy of $\pm 0.03 \mathrm{~mm} / 0.001$ ). The maximum point of stress in both artificial canals was also analyzed.

\section{Statistical Analysis}

A descriptive analysis of the NCF was performed according to the irrigant type $(\mathrm{CHX}$ and $\mathrm{NaOCl})$ in its different formulations ( $\mathrm{G}$ or $\mathrm{L}$ ) and according to the control groups (LO and NAT). The normality and homoscedasticity were confirmed by the Shapiro-Wilk and Levene tests, respectively. Tukey's test was used to compare the averages for the NCF according to the irrigant type (groups =6). The significance level was set at $5 \%$.

\section{Results}

The $\mathrm{CHX}(\mathrm{G}), \mathrm{CHX}(\mathrm{L})$, and OIL (LO) groups showed no significant difference between them and presented longer time and $\mathrm{NCF}$. $\mathrm{NaOCl}(\mathrm{L})$ shows the NCF without significant differences between $\mathrm{NaOCl}(\mathrm{G})$ and NAT. The $\mathrm{NCF}$ of the $\mathrm{NaOCl}(\mathrm{G})$ was statistically similar to the $\mathrm{CHX}(\mathrm{L})$ and statistically lower than the $\mathrm{CHX}(\mathrm{G})$ and OIL groups. NAT did not present a statistical difference of the $\mathrm{NaOCl}(\mathrm{L})$ and $\mathrm{NaOCl}(\mathrm{G})$, and presented a significantly NCF than $\mathrm{CHX}(\mathrm{G})$. The irrigating agents did not significantly influence the length of the file fragment $(p=0.066 ;$ - Table 1$)$.

\section{Discussion}

The experiment was conducted in a noncorrosive stainlesssteel block to ensure the experiments' standardization without influencing other variables. ${ }^{20}$ Because of higher cyclic fatigue resistance than that of the $30 / 0.04 \mathrm{Ni}-\mathrm{Ti}$ rotary instruments immersed in water at simulated body temperature, ${ }^{15}$ XPS instruments were the ideal instrument in this study. The files were subjected to back-and-forth axial movements at a $3.0 \mathrm{~mm} / \mathrm{s}^{21}$ speed to simulate clinical conditions. In the dynamic model, ${ }^{22}$ tensile and compressive stresses are distributed over a wider area throughout the instrument shaft within the artificial canal curvature by moving the file
Table 1 Means and standard deviations of number of fracture cycles and length of file fragments according to each type of irrigating substance

\begin{tabular}{|l|l|l|}
\hline $\begin{array}{l}\text { Irrigating } \\
\text { solution }\end{array}$ & $\begin{array}{l}\text { NCF } \\
\text { Mean (SD) }\end{array}$ & $\begin{array}{l}\text { Fragments } \\
(\mathbf{m m}) \\
\text { Mean (SD) }\end{array}$ \\
\hline $\mathrm{CHX}$ gel 2\% & $1,761(258)^{\mathrm{a}}$ & $4.36(0.20)^{\mathrm{A}}$ \\
\hline $\mathrm{CHX}$ solution 2\% & $1,523(327)^{\mathrm{a}, \mathrm{b}, \mathrm{c}}$ & $4.30(0.20)^{\mathrm{A}}$ \\
\hline $\mathrm{NaOCl}$ solution 5.25\% & $1,028(389)^{\mathrm{d}}$ & $4.51(0.29)^{\mathrm{A}}$ \\
\hline $\mathrm{NaOCl}$ gel 3\% & $1,111(312)^{\mathrm{c}, \mathrm{d}}$ & $4.25(0.21)^{\mathrm{A}}$ \\
\hline Natrosol gel & $1,309(170)^{\mathrm{b}, \mathrm{c}, \mathrm{d}}$ & $4.27(0.16)^{\mathrm{A}}$ \\
\hline Lubricating oil & $1,613(468)^{\mathrm{a}, \mathrm{b}}$ & $4.42(0.19)^{\mathrm{A}}$ \\
\hline$p$-Value & $p<0.001$ & $p=0.066$ \\
\hline
\end{tabular}

Note: Different lowercase letters in the columns indicate statistical difference $(p<0.05)$. Same lowercase letters in the columns indicate that there was no statistical difference $(p>0.05)$.

axially, ${ }^{23}$ enhancing fracture resistance, and could reproduce a clinical up-and-down motion. ${ }^{24}$

The radius and the angle of canal curvature are known to have significant roles in cyclic fatigue failure; lower degrees of curvature will result in longer fracture time. ${ }^{25}$ In the present study, a severe 90-degree curvature of the simulated canal was used to assess the instrument's behavior in critical conditions. $^{19}$

Synthetic oil is a universal substance used to control cyclic fatigue resistance tests in a static or dynamic model. ${ }^{26}$ The natrosol gel (hydroxyethyl cellulose) was also used as a control substance because it is the base of the $\mathrm{CHX}(\mathrm{G})$ and a nonionic agent, highly inert and soluble in water, ${ }^{27}$ similar to the gel used in $\mathrm{NaOCl}(\mathrm{G})$. However, the manufacturer does not disclose the gel substance used in $\mathrm{NaOCl}(\mathrm{G})$.

The present study evaluated the instruments at $37^{\circ} \mathrm{C}$ simulating body temperature (13), whereas previous studies evaluated at room temperature. ${ }^{28,29}$

Despite $\mathrm{NaOCl}$ is potentially irritating for periapical tissues, especially in high concentrations, it is the substance most widely used for root canal irrigation in endodontics because of its effective antimicrobial activity and ability to dissolve organic tissues. ${ }^{30}$ Furthermore, $\mathrm{NaOCl}$ gel has been studied in the efficacy against microorganisms ${ }^{12}$ and in the debris extrusion during endodontic treatment ${ }^{11}$ with promising results.

On the other hand, CHX (L and G formulation) was used in the present study because both $\mathrm{CHX}$ and $\mathrm{NaOCl}$ were equally effective in reducing endodontic infection, despite their different molecular mechanisms. ${ }^{8}$ The main limitation of CHX as an endodontic irrigator is its inability to dissolve pulp tissue. $^{24}$

In this study, $\operatorname{OIL}(\mathrm{LO}), \mathrm{CHX}(\mathrm{L})$, and $\mathrm{CHX}(\mathrm{G})$ did not differ significantly from each other; however, the NCF were statistically higher compared to $\mathrm{NaOCl}(\mathrm{L})(p<0.01)$. Therefore, the null hypothesis was rejected, corroborating with another study. ${ }^{19}$ This result occurred probably due to deteriorations caused by $\mathrm{NaOCl}(\mathrm{L})$ on the surface of the file ${ }^{31}$ and due to a 
galvanic reaction when the file is exposed to an electrolytic solution such as $\mathrm{NaOCl}(\mathrm{L})$, causing corrosion processes predisposing the instruments to unexpected fractures. ${ }^{32}$ In addition, $\mathrm{NaOCl}(\mathrm{L})$ may cause micropitting by removing nickel from the instrument surface, ${ }^{33}$ thereby decreasing the resistance to cyclic fatigue. ${ }^{34}$

On the other side, $\operatorname{CHX}(\mathrm{G})$ provided the endodontic file the most significant resistance to fracture in this experimental model similar to $\mathrm{CHX}(\mathrm{L})$. Chlorhexidine gluconate is a cationic biguanide used as an intracanal irrigant in a liquid ${ }^{32}$ and gel ${ }^{15}$ formulation. The gel base used in the $\mathrm{CHX}(\mathrm{G})$ formulation in the present study was the natrosol gel (hydroxyethyl cellulose), which is a nonionic and inert and water-soluble agent ${ }^{27}$ widely used to thicken shampoos, gels, and soaps based on cationic substances such as chlorhexidine gluconate. The cationic chlorhexidine molecule could avoid galvanic current preventing corrosion of the file metal decreases instrument breakage. ${ }^{15}$ In the present study, CHX $(G)$ had no differences regarding NAT, showing that $\mathrm{CHX}(\mathrm{G})$ increases the resistance to file fracture more by avoiding galvanic corrosion than being a lubricant.

In the $\mathrm{NaOCl}(\mathrm{G})$ group, the time to fracture and the NCF was similar to the one verified with the use of $\operatorname{CHX}(\mathrm{L})$ and NAT but did not reach the time until fracture and NCF verified with the OIL and $\mathrm{CHX}(\mathrm{G})$. When exposed to a $\mathrm{NaOCl}$, even in a $G$ formulation, the lower fracture resistance could be attributed to the induced corrosive zones, which are likely to reduce the resistance to cyclic fatigue of the instrument. ${ }^{35}$ Besides, when exposed to a higher $\mathrm{NaOCl}$ concentration, a decrease in cyclic fatigue resistance is expected due to the increased amount of available chlorine that attacks the metallic league. ${ }^{36} \mathrm{NaOCl}$, when compared with water, negatively affects the fatigue resistance of NiTi instruments, ${ }^{37}$ especially at higher concentrations. ${ }^{38}$

Immersion of instruments in $\mathrm{NaOCl}$ before cyclic fatigue testing for 3 to 5 minutes did not affect the cyclic fatigue of NiTi endodontic instruments. ${ }^{39}$ However, they do not reflect the actual clinical status of root canal preparation in that they are performed in the presence of irrigants in the root canal. The current study kept the simulated canal full of irrigants throughout the experiment, better simulating the clinical conditions. Fatigue failure can be caused initially by cracks on the instrument's surface, which may be due to the concentration of chloride ions in the corrosion reaction under a titanium gap, ${ }^{40}$ influencing instrument fatigue resistance. ${ }^{41}$

The mean lengths of fractured segments were recorded to evaluate the maximum concentration area of the compression and tensile stresses of the tested files inside the canal curvature. There was no significant difference between the groups, regardless of the broken fragments' lengths $(4.5 \pm 0.5 \mathrm{~mm})$. This matches the file's location inside the curvature; the point of maximum stress was similar in each circumstance, suggesting standardization of the experiment. ${ }^{26}$

Based on the current study's findings, it is possible to conclude that CHX $(\mathrm{G})$ and $\mathrm{CHX}(\mathrm{L})$ increased the time to fracture and the NCF of XPS files. In addition, XPS instruments were significantly more resistant to cyclic fatigue when irrigated with $\mathrm{CHX}(\mathrm{G})$ than with $\mathrm{NaOCl}(\mathrm{G}), \mathrm{NaOCl}(\mathrm{L})$, or $\mathrm{CHX}(\mathrm{L})$. However, the circumstances tested in these dynamic models are very different from those present in clinical practice. Therefore, further studies are needed to evaluate other irrigating solutions and their influence on XPS instruments' cyclic fatigue.

\section{Funding \\ None. \\ Conflict of Interest \\ None declared.}

\section{References}

1 Ferreira ACG, Frozoni M, Prado M, Gomes B, Signoretti F, De-JesusSoares A. Current trends in technological armamentarium and treatment among Brazilian endodontists. Braz J Oral Sci 2017;16: e17045-e17045

2 XP-endo Solutions. Accessed on January 24, 2021 at: https:// www.fkg.ch/products/endodontics/canal-shaping-and-cleaning/xp-endo-shaper

3 Azim AA, Piasecki L, da Silva Neto UX, Cruz ATG, Azim KA. XP Shaper, a novel adaptive core rotary instrument: microcomputed tomographic analysis of its shaping abilities. J Endod 2017;43 (09):1532-1538

4 Emara RS, Gawdat SI, El-Far HMM. Effect of XP-endo Shaper versus conventional rotary files on postoperative pain and bacterial reduction in oval canals with necrotic pulps: a randomized clinical study. Int Endod J 2021;54(07):1026-1036

5 Alfadley A, Alrajhi A, Alissa H, et al. Shaping ability of XP endo shaper file in curved root canal models. Int J Dent 2020; 2020:4687045

6 Üreyen Kaya B, Erik CE, Sesli Çetin E, Köle M, Maden M. Mechanical reduction in intracanal Enterococcus faecalis when using three different single-file systems: an ex vivo comparative study. Int Endod J 2019;52(01):77-85

7 Keles A, Uzunoglu Ozyurek E, Uyanik MO, Nagas E. Effect of temperature of sodium hypochlorite on cyclic fatigue resistance of heat-treated reciprocating files. J Endod 2019;45(02):205-208

8 Ruksakiet K, Hanák L, Farkas N, et al. Antimicrobial efficacy of chlorhexidine and sodium hypochlorite in root canal disinfection: a systematic review and meta-analysis of randomized controlled trials. J Endod 2020;46(08):1032-1041

9 Dioguardi M, Gioia GD, Illuzzi G, Laneve E, Cocco A, Troiano G. Endodontic irrigants: different methods to improve efficacy and related problems. Eur J Dent 2018;12(03):459-466

10 Hülsmann M, Hahn W. Complications during root canal irrigation-literature review and case reports. Int Endod J 2000;33(03): 186-193

11 Ozlek E, Neelakantan P, Khan K, Cheung GSP, Rossi-Fedele G. Debris extrusion during root canal preparation with nickel-titanium instruments using liquid and gel formulations of sodium hypochlorite in vitro. Aust Endod J 2021;47(02):130-136. Doi:10.1111/aej.12424

12 Zand V, Lotfi M, Soroush MH, Abdollahi AA, Sadeghi M, Mojadadi A. Antibacterial efficacy of different concentrations of sodium hypochlorite gel and solution on Enterococcus faecalis biofilm. Iran Endod J 2016;11(04):315-319

13 Gomes BP, Vianna ME, Zaia AA, Almeida JF, Souza-Filho FJ, Ferraz CC. Chlorhexidine in endodontics. Braz Dent J 2013;24(02):89-102

14 Pinheiro SL, Silva CCD, Silva LAD, et al. Antimicrobial efficacy of $2.5 \%$ sodium hypochlorite, $2 \%$ chlorhexidine, and ozonated water as irrigants in mesiobuccal root canals with severe curvature of mandibular molars. Eur J Dent 2018;12(01):94-99 
15 Ferraz CC, Gomes BP, Zaia AA, Teixeira FB, Souza-Filho FJ. In vitro assessment of the antimicrobial action and the mechanical ability of chlorhexidine gel as an endodontic irrigant. J Endod 2001;27 (07):452-455

16 Vianna ME, Gomes BP, Berber VB, Zaia AA, Ferraz CC, de SouzaFilho FJ. In vitro evaluation of the antimicrobial activity of chlorhexidine and sodium hypochlorite. Oral Surg Oral Med Oral Pathol Oral Radiol Endod 2004;97(01):79-84

17 Jain K, Agarwal P, Jain S, Seal M, Adlakha T. Alexidine versus chlorhexidine for endodontic irrigation with sodium hypochlorite. Eur J Dent 2018;12(03):398-402

18 Sattapan B, Nervo GJ, Palamara JE, Messer HH. Defects in rotary nickel-titanium files after clinical use. J Endod 2000;26(03): 161-165

19 Medeiros E Jr, Limoeiro AG, Tanomaro A, et al. Influence of sodium hypochlorite and chlorexidine on the dynamic cyclic fatigue resistance of XP-Endo Finisher instruments. G Ital Endod 2021; 35(01):13-19. Doi: 10.32067/GIE.2021.35.01.06

20 Yao JH, Schwartz SA, Beeson TJ. Cyclic fatigue of three types of rotary nickel-titanium files in a dynamic model. J Endod 2006;32 (01):55-57

21 Adiguzel M, Isken I, Pamukcu II. Comparison of cyclic fatigue resistance of XP-endo Shaper, HyFlex CM, FlexMaster and Race instruments. J Dent Res Dent Clin Dent Prospect 2018;12(03): 208-212

22 Palma PJ, Messias A, Cerqueira AR, et al. Cyclic fatigue resistance of three rotary file systems in a dynamic model after immersion in sodium hypochlorite. Odontology 2019;107(03):324-332

23 Dederich DN, Zakariasen KL. The effects of cyclical axial motion on rotary endodontic instrument fatigue. Oral Surg Oral Med Oral Pathol 1986;61(02):192-196

24 Rodrigues RC, Lopes HP, Elias CN, Amaral G, Vieira VT, De Martin AS. Influence of different manufacturing methods on the cyclic fatigue of rotary nickel-titanium endodontic instruments. J Endod 2011;37(11):1553-1557

25 Gambarini G, Galli M, Di Nardo D, Seracchiani M, Donfrancesco O, Testarelli L. Differences in cyclic fatigue lifespan between two different heat treated NiTi endodontic rotary instruments: WaveOne Gold vs EdgeOne Fire. J Clin Exp Dent 2019;11(07):e609-e613

26 Serafin M, De Biasi M, Franco V, Angerame D. In vitro comparison of cyclic fatigue resistance of two rotary single-file endodontic systems: OneCurve versus OneShape. Odontology 2019;107(02): 196-201

27 Miyamoto T, Takahashi S, Ito H, Inagaki H, Noishiki Y. Tissue biocompatibility of cellulose and its derivatives. J Biomed Mater Res 1989;23(01):125-133
28 Pérez-Higueras JJ, Arias A, de la Macorra JC, Peters OA. Differences in cyclic fatigue resistance between ProTaper Next and ProTaper Universal instruments at different levels. J Endod 2014;40(09): 1477-1481

29 Plotino G, Grande NM, Cotti E, Testarelli L, Gambarini G. Blue treatment enhances cyclic fatigue resistance of vortex nickeltitanium rotary files. J Endod 2014;40(09):1451-1453

30 Zehnder M. Root canal irrigants. J Endod 2006;32(05):389-398

31 Elnaghy A, Elsaka S. Cyclic fatigue resistance of XP-endo Shaper compared with different nickel-titanium alloy instruments. Clin Oral Investig 2018;22(03):1433-1437

32 Rôças IN, Siqueira JF Jr. Comparison of the in vivo antimicrobial effectiveness of sodium hypochlorite and chlorhexidine used as root canal irrigants: a molecular microbiology study. J Endod 2011;37(02):143-150

33 Sarkar NK, Redmond W, Schwaninger B, Goldberg AJ. The chloride corrosion behaviour of four orthodontic wires. J Oral Rehabil 1983;10(02):121-128

34 Berutti E, Angelini E, Rigolone M, Migliaretti G, Pasqualini D. Influence of sodium hypochlorite on fracture properties and corrosion of ProTaper Rotary instruments. Int Endod J 2006;39 (09):693-699

35 Shen Y, Qian W, Abtin H, Gao Y, Haapasalo M. Effect of environment on fatigue failure of controlled memory wire nickel-titanium rotary instruments. J Endod 2012;38(03):376-380

36 Suresh S. Fatigue of Materials. 2nd ed. Cambridge, UK: Cambridge University Press; 1998

37 Pedullà E, Benites A, La Rosa GM, et al. Cyclic fatigue resistance of heat-treated nickel-titanium instruments after immersion in sodium hypochlorite and/or sterilization. J Endod 2018;44(04): 648-653

38 Alfawaz H, Alqedairi A, Alsharekh H, Almuzaini E, Alzahrani S, Jamleh A. Effects of sodium hypochlorite concentration and temperature on the cyclic fatigue resistance of heat-treated nickel-titanium rotary instruments. J Endod 2018;44(10): 1563-1566

39 Huang X, Shen Y, Wei X, Haapasalo M. Fatigue resistance of nickeltitanium instruments exposed to high-concentration hypochlorite. J Endod 2017;43(11):1847-1851

40 Satoh H, Shimogori K, Kamikubo F. The crevice corrosion resistance of some titanium materials. Platin Met Rev 1987; 31:115-121

41 Darabara M, Bourithis L, Zinelis S, Papadimitriou GD. Susceptibility to localized corrosion of stainless steel and NiTi endodontic instruments in irrigating solutions. Int Endod J 2004;37(10): 705-710 